\title{
Economic Evaluation and Yield Performance of Some Medicinal Plants in Coconut Based Multistoried Agroforestry Systems
}

\author{
M. S. Bari ${ }^{1 *}$ and M. A. Rahim ${ }^{2}$ \\ ${ }^{1}$ Dept. of Agroforestry, Hajee Mohammad Danesh Science \&Technology University, Bangladesh \\ ${ }^{2}$ Dept. of Horticulture, Bangladesh Agricultural University, Mymensingh, Bangladesh \\ *Corresponding author and Email: shafiqul_bari@yahoo.com
}

Received: 16 November 2011

Accepted: 26 May 2012

\begin{abstract}
An experiment was conducted at the existing multistoried coconut orchard of the Horticulture Farm of Bangladesh Agricultural University, Mymensingh to investigate the performance of three medicinal plants viz. aloe vera (Aloe indica), asparagus (Asparagus racemosus) and misridana (Kaempferia angustifolia) in coconut based multistoried agroforestry system (MAF) during March 2005 to March 2007. The experiment was laid out in a randomized complete block design with five replications. Three treatments combinations were: $\mathrm{T}_{1}-$ coconut + guava + individual three medicinal plant based agroforestry system, $\mathrm{T}_{2}$ - coconut + lemon + individual three medicinal plant based agroforestry system, and $\mathrm{T}_{3}$ - individual three medicinal plants in open condition. In the open condition, $\mathrm{T}_{3}$ received $100 \%$ sunlight; while coconut + guava based system $\left(\mathrm{T}_{1}\right)$ and coconut + lemon based system $\left(\mathrm{T}_{2}\right)$ were allowed 42 to $46 \%$ and 53 to $58 \%$ sunlight for the growth of the three medicinal plants, respectively. Coconut trees were planted thirty years before (August, 1978) in the spacing of $8 \mathrm{~m} \mathrm{x} \mathrm{8m}$. As the middle layer plant, both guava and lemon were five years old. Spacing between plants of guava and/or lemon and between rows were $3 \mathrm{~m} \times 3 \mathrm{~m}$. The result showed that multistoried agroforestry systems resulted significant influence on yield and yield attributing parameters of the three medicinal plants. The results also revealed that among the three medicinal plants, asparagus and misridana produced maximum yield under MAF, while aloe vera yielded maximum in sole cropping. Despite of lower yields of aloe vera, the highest gross returns were observed under coconut based multistoried agroforestry systems compared to sole cropping. It was due to the substantial additional contribution by coconut, guava and lemon fruits in MAF, while extra benefit was absent under sole cropping condition. Moreover, between the two different combinations of coconut based multistoried agroforestry systems, the highest benefit cost ratio (BCR) was recorded from the coconut+guava based $\operatorname{MAF}\left(\mathrm{T}_{1}\right)$.
\end{abstract}

Keywords: Multistoried agroforestry system, coconut, guava, lemon, medicinal plants

\section{Introduction}

Exploitation of herbal wealth from forests for pharmaceutical purposes is an old practice, where medicinal plants have remained an essential component of natural vegetation in
Bangladesh. There are more than 500 species of medicinal plants that have been listed from the ground level vegetation of the forest and villages groves in Bangladesh (FAO, 2004). Many of those are used by the rural people and the tribal communities for human and animal treatments. 
However, these valuable medicinal plant species have been reported to be disappearing rapidly due to heavy demand from pharmaceutical industry, leading to over exploitation and destruction of habitats. Again, due to over exploitation and unscientific collections, the genetic resources of valuable medicinal plants are being exhausted very fast. To overcome this situation, it is necessary that the cultivation of medicinal plant species in various agroforestry systems be exploited at commercial level to boosts up the production of medicines and achieves the target of providing cheaper medicines.

Many tropical medicinal plants are well adapted to partial shading, moist soil, high relative humidity and mild temperatures (Vyas and Nein, 1999; Sujatha et al., 2010), allowing them to be intercropped with timber and fuel wood plantations, fruit trees and plantation crops. Some well known medicinal plants that have been successfully intercropped with fuel wood trees (e.g, Acacia auriculiformis, Albizia lebbeck, Eucalyptus tereticornis, Gmelina arborea, and Leucaeana leucocephala) in India, include safed musli (Chlorophytum borivilianum), rauvolfia (Rauvolfia sarpentina), turmeric (Curcuma longa), wild turmeric ( $C$. aromatica), Curculigo orchioides, and ginger (Zingiber officinale) (Chadhar and Sharma, 1996; Mishra and Pandey, 1998; Prajapati et al., 2003). Now, there is every need to promote the cultivation of medicinal plants under agroforestry systems in agriculture as well as wasteland of the country. Shift from collection to cultivation of medicinal plants will also ensure purity, authenticity and sustainable supply of raw materials required for herbal drugs. However, there is no specific information on the feasibility of growing medicinal plants with multipurpose tree species, except for the exploratory studies made on inclusion of some medicinal plants in India, which showed improved profitability (Pareek and Gupta, 1984; Maheshwari et al., 1985; Rao et al., 2004). It is therefore, necessary to identify suitable medicinal plants to be integrated with multipurpose tree species to develop potential, diversified and profitable agroforestry system. In addition, there is a strong need to develop cultural practices to raise these plants as part of agri-silviculture or agrihorticulture systems. The present experiments were therefore; conducted to evaluate the performance of three commercial and important medicinal plants like aloe vera (Aloe indica), asparagus (Asparagus racemosus) and misridana (Kaempferia angustifolia) as intercrops under coconut based multistoried agroforestry system.

\section{Materials and Methods}

The experiment was conducted in the existing multistoried coconut garden of the Department of Horticulture, Bangladesh Agricultural University, Mymensingh during 2005-2007. The experimental area was under sub-tropical climate characterized by heavy rainfall during the months from April to September and scanty rainfall during the rest period of the year. The soil of the experimental area was silty loam in texture. It was also a medium high land with fertile and well drained soils. The experiment was laid out in a randomized complete block design with five replications and three treatments. The first treatment $\left(\mathrm{T}_{1}\right)$ was coconut+guava+ individual three medicinal plants based multistoried Agroforestry system. The second treatment was $\left(\mathrm{T}_{2}\right)$ coconut+lemon+ individual three medicinal plants based multistoried Agroforestry system and the third was $\left(T_{3}\right)$ control. Both the treatments $T_{1}$ and $T_{2}$ were three layered garden consisted of coconut at the top layer, guava and lemon at the middle layer; and the individual three medicinal plants were at the ground layer. In case of control treatment $\left(\mathrm{T}_{3}\right)$, all the three medicinal plants were cultivated in open condition i.e. as sole cropping. In the open condition, $\mathrm{T}_{3}$ treatment received $100 \%$ sunlight; while coconut + guava based multistoried Agroforestry system $\left(\mathrm{T}_{1}\right)$ and coconut + lemon based multistoried Agroforestry system $\left(\mathrm{T}_{2}\right)$ were allowed, respectively 42 to $46 \%$ and 53 to $58 \%$ sunlight for the growth of the medicinal plants.

The coconut tree was planted in August, 1978 (thirty years old) and the spacing of plantation 
was $8 \mathrm{~m} \times 8 \mathrm{~m}$. As the middle or second layer plant, both guava and lemon were planted in August, 2000 (five years old) and were in full bearing condition. Spacing between guava and/or lemon and between rows was $3 \mathrm{~m} \times 3 \mathrm{~m}$. Coconut, guava and lemon trees were not dressed with any fertilizer. However, the ground layer crops i.e. medicinal crops were fertilized with the recommended doses of fertilizers consisting of cowdung, urea, triple super phosphate (TSP) and muriate of potash (MP).

Seedlings of aloe vera and asparagus were planted on 27 February 2005 and 9 March 2005, respectively. The mother rhizomes of misridana were also planted in the experimental plot on 3 March 2005 and 12 March 2006. These planting materials were collected from Haybotpur village of Natore district. The spacing of the planting was $60 \mathrm{~cm} \times 45 \mathrm{~cm}$ for both aloe vera and asparagus and $50 \mathrm{~cm} \mathrm{x} 40 \mathrm{~cm}$ for misridana. The experimental plots were kept weed free by manual weeding frequently. The plots were irrigated whenever needed using hose pipe and watering cane.

Economics of various treatments was analyzed taking into account the current costs of inputs and produce. Data on various growth and yield attributes of aloe vera, asparagus and misridana were statistically analyzed to examine the significant variation of the results due to different shading condition. The analysis of variance for each of the character was done by $\mathrm{F}$ (Variance ratio) test following Randomized Complete Block Design (RCBD). The treatment means were compared at 1 and 5 per cent level of significance (using MSTAT computer and Excel Programme).

\section{Results and Discussions}

\subsection{Performance of aloe vera}

\subsubsection{Growth and yield contributing characters}

Plant height of aloe vera was not significantly influenced by different production systems and it ranged from 41.92 to $46.98 \mathrm{~cm}$ (Table 1). The tallest plant $(46.98 \mathrm{~cm})$ of aloe vera was found in coconut+lemon based MAF $\left(\mathrm{T}_{1}\right)$ and the shortest plant $(41.92 \mathrm{~cm})$ was recorded in sole cropping $\left(T_{3}\right)$. Number of leaves per plant of aloe vera was significantly influenced by treatments and the maximum number of leaves (10.66) was obtained in sole cropping $\left(\mathrm{T}_{3}\right)$ followed by coconut+lemon based MAF $\left(\mathrm{T}_{2}\right)$. Notably, the lowest number of leaves (7.90) was found in coconut+guava based MAF $\left(\mathrm{T}_{1}\right)$. Similarly, leaf length of aloe vera varied markedly. The trend of leaf length under different production systems was nearly parallel to that of plant height.

Width of aloe vera leaves increased gradually with the decrease in shade level. The maximum leaf width $(5.34 \mathrm{~cm})$ was recorded from the sole cropping of aloe $\left(\mathrm{T}_{3}\right)$, which was statistically similar to that produced from the treatments $T_{2}$. The minimum leaf width $(4.05 \mathrm{~cm})$ was recorded from the coconut+guava based MAF $\left(T_{1}\right)$. Individual fresh weight of aloe vera leaf was also decreased as the light interception decreased. The maximum fresh leaf weight (413.9 g) was observed in sole cropping $\left(\mathrm{T}_{3}\right)$, which was significantly higher than those of the $T_{1}$ and $T_{2}$. On the other hand, the minimum fresh leaf weight $(262.8 \mathrm{~g})$ was produced under coconut+guava based MAF $\left(\mathrm{T}_{1}\right)$.

\subsubsection{Yield (t/ha)}

Leaf yield of aloe vera was significantly influenced by different production systems. In general, leaf yield was increased with the increased light level (Table 1). The highest total yield $(31.10 \mathrm{t} / \mathrm{ha})$ was recorded under sole cropping $\left(\mathrm{T}_{3}\right)$, which was followed by treatment $\mathrm{T}_{2}$ (coconut+lemon based MAF). The lowest yield $(18.53 \mathrm{t} / \mathrm{ha})$ was recorded in coconut+guava based MAF $\left(\mathrm{T}_{1}\right)$ which was 37.20 per cent less than the sole cropping $\left(\mathrm{T}_{3}\right)$. The reason of maximum yield reduction in MAF might be that upper and middle layer trees canopy made shade on the entire ground layer plots, consequently shading effect on aloe vera was prevailed which resulted in lower yield. Shading reduced the photosynthesis rate and as a result produced less biomass. Shading also resulted in greater specific leaf area. 
Table 1. Growth and yield of aloe vera as influenced by the coconut based agroforestry system

\begin{tabular}{|c|c|c|c|c|c|c|c|c|c|c|}
\hline \multirow{2}{*}{ Treatments } & \multirow{2}{*}{$\begin{array}{l}\text { Plant } \\
\text { height } \\
(\mathrm{cm})\end{array}$} & \multirow{2}{*}{$\begin{array}{l}\text { No. of } \\
\text { leaves } \\
\text { plant }^{-1}\end{array}$} & \multirow{2}{*}{$\begin{array}{l}\text { Leaf } \\
\text { length } \\
(\mathrm{cm})\end{array}$} & \multirow{2}{*}{$\begin{array}{l}\text { Leaves } \\
\text { width } \\
(\mathrm{cm})\end{array}$} & \multirow{2}{*}{$\begin{array}{l}\text { Canopy } \\
\text { volume } \\
\left(\mathrm{cm}^{3}\right)\end{array}$} & \multirow{2}{*}{$\begin{array}{l}\text { Leaves } \\
\text { fresh wt } \\
\text { plant }^{-1}(g)\end{array}$} & \multirow{2}{*}{$\begin{array}{l}\text { Leaves } \\
\text { dry wt. }_{\text {plant }^{-1}(\mathrm{~g})}\end{array}$} & \multicolumn{3}{|l|}{ Yield (t/ha) } \\
\hline & & & & & & & & $1^{\text {st }}$ harvest & $\begin{array}{l}2^{\text {nd }} \\
\text { harvest }\end{array}$ & Total \\
\hline Coconut+Guava+Aloe vera $\left(\mathrm{T}_{1}\right)$ & 46.98 & 7.90 & 37.31 & 4.05 & 8963.00 & 262.76 & 13.69 & 7.48 & 11.00 & 18.53 \\
\hline Coconut+Lemon+Aloe vera $\left(T_{2}\right)$ & 42.97 & 9.16 & 35.90 & 4.59 & 10527.97 & 290.49 & 17.01 & 9.73 & 12.75 & 22.48 \\
\hline Open $\left(\mathrm{T}_{3}\right)$ & 41.92 & 10.66 & 34.12 & 5.34 & 12504.88 & 413.90 & 25.73 & 13.28 & 17.40 & 31.10 \\
\hline $\operatorname{Lsd}_{0.01}$ & - & 2.29 & 3.40 & 1.10 & 1831.22 & 61.35 & 3.79 & 2.89 & 2.94 & 6.57 \\
\hline Level of signi. & NS & $* *$ & $* *$ & $* *$ & $* *$ & $* *$ & $* *$ & $* *$ & $* *$ & $* *$ \\
\hline CV (\%) & 8.33 & 11.68 & 4.48 & 11.16 & 8.09 & 8.97 & 9.61 & 13.42 & 10.11 & 12.88 \\
\hline
\end{tabular}

** Significant at 0.01 level; NS = Not significant; $\mathrm{CV}=$ coefficient of variation 


\subsubsection{Economic analysis}

The economics of cultivation of aloe vera solely as well as together with coconut, guava and lemon trees has been analyzed to ascertain economically profitable combinations as feasible for Bangladesh conditions. Table 2 indicates that the total cost of production was the highest (107428 Tk./ha) in sole cropping $\left(\mathrm{T}_{3}\right)$ followed by coconut+guava based MAF (80693 Tk./ha) $\left(\mathrm{T}_{1}\right)$. The lowest cost of production (78546 Tk./ha) was recorded in coconut+lemon based MAF $\left(\mathrm{T}_{2}\right)$. Higher cost of production was found in sole cropping of aloe vera due to larger area being cultivated $(100 \%)$ for aloe vera production as compared to coconut based MAF $(25 \%)$, as a result more input cost was required. However, the highest gross return (285922 Tk. /ha) was obtained from the coconut+guava based MAF $\left(\mathrm{T}_{1}\right)$, which was followed by the coconut+lemon based MAF $\left(\mathrm{T}_{2}\right)$. The highest benefit-cost ratio of 3.54 was recorded from coconut+guava based MAF $\left(\mathrm{T}_{1}\right)$ which was followed by coconut+lemon based MAF $\left(\mathrm{T}_{2}\right)$. The lowest benefit-cost ratio of 1.65 was observed in sole cropping $\left(\mathrm{T}_{3}\right)$ (Table 2). Aloe vera can therefore be advantageously cultivated in coconut based multistoried agroforestry systems.

\subsection{Performance of asparagus}

\subsubsection{Growth and yield contributing characters}

Plant height of asparagus was substantially influenced by different production systems and it ranged from 75.30 to $126.8 \mathrm{~cm}$ (Table 3 ). The tallest plant $(126.8 \mathrm{~cm})$ of asparagus was found in coconut+guava based MAF $\left(\mathrm{T}_{1}\right)$. Again, the intermediate plant height was recorded in the plants grown under coconut+lemon based MAF $\left(\mathrm{T}_{2}\right)$ and the shortest plant $(75.30 \mathrm{~cm})$ was recorded in sole cropping $\left(\mathrm{T}_{3}\right)$. A significant variation was also observed in canopy volume of asparagus plant due to the practice of different production systems. It is clear from Table 3 that the canopy volume of asparagus was gradually decreased with the decreasing of light availability. The maximum canopy volume of asparagus $\left(117680 \mathrm{~cm}^{3}\right)$ was recorded in sole cropping of asparagus $\left(\mathrm{T}_{3}\right)$. Among the two MAF, coconut+guava based MAF produced lower canopy volume than coconut+lemon based MAF. The minimum canopy volume of asparagus $\left(91473 \mathrm{~cm}^{3}\right)$ was produced in coconut+guava based MAF $\left(\mathrm{T}_{1}\right)$. Number of tuberous roots per plant of asparagus was also significantly influenced and the maximum number of tuberous roots per plant (59.86) was obtained in coconut+lemon based $\operatorname{MAF}\left(\mathrm{T}_{2}\right)$ followed by sole cropping $\left(\mathrm{T}_{3}\right)$. The lowest number of tubers (38.80) was found in coconut+guava based MAF $\left(\mathrm{T}_{1}\right)$. Length of tuberous roots of asparagus varied markedly and the trend of tuberous root length under different production systems was similar to that of number of tuberous roots per plant. The maximum tuberous roots length $(15.45 \mathrm{~cm})$ was observed in coconut+lemon based MAF $\left(\mathrm{T}_{2}\right)$, which was statistically similar to the treatments $\mathrm{T}_{3}$.

Table 2. Economics of aloe vera production under coconut based multistoried cropping system

\begin{tabular}{|c|c|c|c|c|c|c|c|c|}
\hline \multirow{2}{*}{ Treatments } & \multicolumn{4}{|c|}{ Return (Tk/ha) } & \multirow{2}{*}{$\begin{array}{c}\text { Gross } \\
\text { Return } \\
\left(\mathrm{Tk} . \mathrm{ha}^{-1}\right)\end{array}$} & \multirow{2}{*}{$\begin{array}{l}\text { Total cost of } \\
\text { Production } \\
\left(\mathrm{Tk} . \mathrm{ha}^{-1}\right)\end{array}$} & \multirow{2}{*}{$\begin{array}{l}\text { Net } \\
\text { Return } \\
\left(\text { Tk. ha }{ }^{-1}\right)\end{array}$} & \multirow{2}{*}{$\mathrm{BCR}$} \\
\hline & $\begin{array}{l}\text { Aloe } \\
\text { vera }\end{array}$ & Guava & Lemon & Coconut & & & & \\
\hline Coconut+Guava + Aloe vera $\left(\mathrm{T}_{1}\right)$ & 18530 & 172080 & --- & 95312 & 285922 & 80693 & 205229 & 3.54 \\
\hline Coconut+Lemon+Aloe ver $\left(\mathrm{T}_{2}\right)$ & 22480 & --- & 103837 & 95312 & 221629 & 78546 & 143083 & 2.82 \\
\hline Open $\left(T_{3}\right)$ & 124400 & --- & --- & --- & 177330 & 107428 & 69902 & 1.65 \\
\hline
\end{tabular}

Note: Aloe vera 4 tk./kg, Guava 6 Tk./kg; Lemon 1 Tk./piece, Coconut 8Tk./nut 
The minimum tuberous roots length $(13.08 \mathrm{~cm})$ of asparagus was observed in plants grown under coconut+guava based MAF $\left(\mathrm{T}_{1}\right)$, which was also statistically similar to the sole cropping of asparagus $\left(\mathrm{T}_{3}\right)$. Again, the highest root diameter $(1.742 \mathrm{~cm})$ was recorded in the coconut+lemon based MAF $\left(\mathrm{T}_{2}\right)$, which was statistically similar to that produced from the sole cropping. The trend of fresh weight of tuberous roots under different production systems was also similar to that of number of tuberous roots per plant. The maximum fresh root weight $(342.3 \mathrm{~g})$ was observed in coconut+lemon based $\operatorname{MAF}\left(\mathrm{T}_{2}\right)$, which was followed by the treatment $\mathrm{T}_{3}$. On the other hand, the minimum fresh root weight (195.2 g) was produced under coconut+guava based MAF $\left(\mathrm{T}_{1}\right)$. Table 3 suggests that root dry weight of asparagus was significantly prejudiced by the different production systems. Coconut+lemon based MAF produced higher root dry weight per plant than that of coconut+guava based MAF. Consequently, the maximum root dry weight $(32.28 \mathrm{~g})$ was observed in coconut+lemon based $\operatorname{MAF}\left(\mathrm{T}_{2}\right)$, which was followed by the treatment $T_{3}$. Reversely, the minimum root dry weight (17.10 g) was produced under coconut+guava based MAF $\left(T_{1}\right)$. Nevertheless, the pattern of root dry weight observed was as $T_{2}>T_{3}>T_{1}$.

\subsubsection{Yield (t/ha)}

Yield of asparagus was significantly influenced by different production systems. In general, root yield of asparagus was increased with the increase in light level (Table 1). Once more, partial shade conditions gave more root yield as compared to severe shade conditions. The highest yield (14.61 t/ha) was recorded in coconut + lemon based MAF $\left(\mathrm{T}_{2}\right)$, which was followed by the treatment $\mathrm{T}_{3}$. The lowest yield (8.20 t/ha) was recorded in coconut+guava based MAF $\left(\mathrm{T}_{1}\right)$. This yield reduction was 31.95 per cent over the sole cropping.

\subsubsection{Economic analysis}

The cost of production of asparagus, middle and upper layer tree plantation and management cost as well as the return from the product and benefit cost ratio (BCR) have been presented in Table 4. The total cost of production was the highest (160875 Tk./ha) in sole cropping of asparagus followed by coconut+guava based MAF (94054 Tk./ha). The lowest cost of production (91907 $\mathrm{Tk} . / \mathrm{ha}$ ) was recorded in coconut+lemon based MAF. Higher cost of production was found in sole cropping of asparagus because higher area was cultivated $(100 \%)$ for asparagus production as compared to coconut based MAF (25\%), and accordingly, more input cost was involved. However, the highest value of gross return (302102 Tk./ha) was obtained from the coconut+guava based MAF $\left(\mathrm{T}_{1}\right)$, which was followed by the sole cropping of asparagus $\left(\mathrm{T}_{3}\right)$. In contrast, the lowest value of gross return (283001 Tk. /ha) was obtained from coconut+lemon based $\operatorname{MAF}\left(\mathrm{T}_{2}\right)$. Among the treatments, it was found that the highest benefitcost ratio of 3.21 was recorded from coconut+guava based MAF $\left(\mathrm{T}_{1}\right)$ followed by coconut+lemon based MAF $\left(\mathrm{T}_{2}\right)$. The lowest benefit-cost ratio of 1.87 was observed in sole cropping $\left(\mathrm{T}_{3}\right)$. Asparagus can therefore be profitably cultivated in coconut based multistoried agroforestry systems.

\subsection{Performance of misridana 3.3.1. Growth and yield contributing characters}

Plant height of misridana at 120 DAP ranged from 33.80 to $51.05 \mathrm{~cm}$ in 2005 and 32.38 to $40.01 \mathrm{~cm}$ in 2006 (Tables 5 and 6). The height was augmented gradually with the lowering of light intensity. The tallest plant $(51.05 \mathrm{~cm}))$ of misridana was observed in coconut+guava based MAF $\left(T_{1}\right)$, which was followed by the treatment $\mathrm{T}_{2}$ during both the growing years. On the contrary, the shortest plant was found in sole cropping of misridana. The corresponding figure of the coconut+lemon based MAF $\left(\mathrm{T}_{2}\right)$ was $37.34 \mathrm{~cm}$ in 2005 and $35.65 \mathrm{~cm}$ in 2006. Again, plant heights $(\mathrm{cm})$ of misridana at 180 DAP ranged from $38.21 \mathrm{~cm}$ to $53.03 \mathrm{~cm}$ in 2005 and $39.86 \mathrm{~cm}$ to $48.68 \mathrm{~cm}$ in 2006 . The pattern of plant height observed was as $T_{1}>T_{2}>T_{3}$ during both the year. 
Table 3. Growth and yield of asparagus as influenced by coconut based multistoried agroforestry systems

\begin{tabular}{|c|c|c|c|c|c|c|c|c|}
\hline Treatments & $\begin{array}{c}\text { Plant } \\
\text { height } \\
(\mathrm{cm})\end{array}$ & $\begin{array}{c}\text { Canopy } \\
\text { volume } \\
\left(\mathrm{cm}^{3}\right)\end{array}$ & $\begin{array}{c}\text { Tuber No. } \\
\text { plant }^{-1}\end{array}$ & $\begin{array}{c}\text { Tuber } \\
\text { length }(\mathrm{cm})\end{array}$ & $\begin{array}{c}\text { Tuber } \\
\text { diameter } \\
(\mathrm{cm})\end{array}$ & $\begin{array}{c}\text { Tuber fresh } \\
\text { wt plant }^{-1}(\mathrm{~g})\end{array}$ & $\begin{array}{c}\text { Tuber dry wt. } \\
\text { plant }^{-1}(\mathrm{~g})\end{array}$ & $\begin{array}{l}\text { Fresh tuber } \\
\text { yield ( } \mathrm{t} / \mathrm{ha} \text { ) }\end{array}$ \\
\hline $\mathrm{C}+\mathrm{G}+$ Asparagus $\left(\mathrm{T}_{1}\right)$ & 126.80 & 91473 & 38.80 & 13.08 & 1.21 & 195.24 & 17.10 & 8.20 \\
\hline $\mathrm{C}+\mathrm{L}+$ Asparagus $\left(\mathrm{T}_{2}\right)$ & 94.29 & 103630 & 59.86 & 15.45 & 1.74 & 342.33 & 32.28 & 14.61 \\
\hline Open $\left(\mathrm{T}_{3}\right)$ & 75.30 & 117680 & 40.66 & 14.72 & 1.67 & 274.08 & 28.83 & 12.05 \\
\hline $\operatorname{Lsd}_{0.01}$ & 13.81 & 6736.54 & 7.65 & 2.11 & 0.30 & 42.95 & 5.09 & 2.66 \\
\hline Level of signi. & $* *$ & $* *$ & $* *$ & $* *$ & $* *$ & $* *$ & $* *$ & $* *$ \\
\hline $\mathrm{CV}(\%)$ & 6.59 & 9.63 & 7.77 & 6.89 & 8.83 & 7.48 & 9.19 & 10.80 \\
\hline
\end{tabular}

Table 4. Economics of asparagus production under coconut based multistoried cropping system

\begin{tabular}{|c|c|c|c|c|c|c|c|c|}
\hline \multirow{2}{*}{ Treatments } & \multicolumn{4}{|c|}{ Return (Tk./ha) } & \multirow{2}{*}{$\begin{array}{l}\text { Gross Return } \\
\quad\left(\mathrm{Tk} . \mathrm{ha}^{-1}\right)\end{array}$} & \multirow{2}{*}{$\begin{array}{l}\text { Total cost of } \\
\text { Production } \\
\left(\mathrm{Tk} . \mathrm{ha}^{-1}\right)\end{array}$} & \multirow{2}{*}{$\begin{array}{l}\text { Net Return } \\
\left(\mathrm{Tk} . \mathrm{ha}^{-1}\right)\end{array}$} & \multirow{2}{*}{$\mathrm{BCR}$} \\
\hline & Asparagus & Guava & Lemon & Coconut & & & & \\
\hline $\mathrm{C}+\mathrm{G}+$ Asparagus $\left(\mathrm{T}_{1}\right)$ & 51250 & 155540 & --- & 95312 & 302102 & 94054 & 208048 & 3.21 \\
\hline $\mathrm{C}+\mathrm{L}+$ Asparagus $\left(\mathrm{T}_{2}\right)$ & 91313 & ---- & 96376 & 95312 & 283001 & 91907 & 191094 & 3.08 \\
\hline Open $\left(\mathrm{T}_{7}\right)$ & 301250 & ---- & --- & --- & 301250 & 160875 & 140375 & 1.87 \\
\hline
\end{tabular}

Note: $\mathrm{C}$ =coconut; $\mathrm{G}=$ guava; $\mathrm{L}=$ lemon; Asparagus 25 Tk./kg, Guava 6 Tk./kg; Lemon 1 Tk./piece, Coconut 8 Tk./nut. 
Table 5. Growth and yield of misridana as influenced by the coconut based multistoried agroforestry systems during March 2005 to December 2005

\begin{tabular}{|c|c|c|c|c|c|c|c|c|c|c|c|}
\hline Treatments & $\begin{array}{c}\text { Plant height } \\
\text { at } 120 \text { DAP } \\
(\mathrm{cm})\end{array}$ & $\begin{array}{c}\text { Plant height } \\
\text { at } 180 \text { DAP } \\
(\mathrm{cm})\end{array}$ & $\begin{array}{c}\text { Leaves } \\
\text { No. } \\
\text { plant }^{-1}\end{array}$ & $\begin{array}{c}\text { Tiller } \\
\text { No hill }^{-1}\end{array}$ & $\begin{array}{l}\text { Mother } \\
\text { rhizome } \\
\text { wt.hill }^{-1}(\mathrm{~g})\end{array}$ & $\begin{array}{c}\text { Primary } \\
\text { fingers } \\
\text { No. } \\
\text { plant }^{-1} \\
\end{array}$ & $\begin{array}{c}\text { Primary } \\
\text { fingers } \\
\text { wt. plant } \\
\text { i }(\mathrm{g})\end{array}$ & $\begin{array}{l}\text { Secondary } \\
\text { fingers No. } \\
\text { plant }^{-1}\end{array}$ & $\begin{array}{l}\text { Secondary } \\
\text { fingers wt. } \\
\text { plant }^{-1}(\mathrm{~g})\end{array}$ & $\begin{array}{c}\text { Total } \\
\text { rhizome } \\
\text { fresh wt } \text { plant }^{-1}(\mathrm{~g}) \\
\end{array}$ & $\begin{array}{l}\text { Yield } \\
\text { (t/ha) }\end{array}$ \\
\hline C+G+Misridana (T1) & 51.05 & 53.03 & 14.76 & 9.42 & 37.80 & 46.12 & 154.73 & 13.90 & 15.05 & 207.84 & 9.57 \\
\hline $\mathrm{C}+\mathrm{L}+$ Misridana $(\mathrm{T} 2)$ & 37.34 & 45.57 & 13.22 & 8.08 & 29.52 & 31.88 & 127.31 & 11.90 & 12.69 & 165.75 & 7.49 \\
\hline Open (T3) & 33.80 & 38.21 & 12.16 & 6.70 & 30.79 & 36.64 & 111.66 & 7.82 & 10.19 & 150.65 & 6.91 \\
\hline Lsd 0.01 & 7.64 & 6.27 & 1.84 & 1.41 & 3.92 & 11.97 & 17.42 & 1.47 & 1.45 & 23.39 & 1.21 \\
\hline $\mathrm{CV}(\%)$ & 8.84 & 6.48 & 6.49 & 8.26 & 5.65 & 8.97 & 6.25 & 6.20 & 5.41 & 6.31 & 8.12 \\
\hline
\end{tabular}

LSD = Least Significant Difference; $\mathrm{C}=$ coconut; $\mathrm{G}=$ guava; $\mathrm{L}=$ lemon

Table 6. Growth and yield of misridana as influenced by the coconut based multistoried agroforestry systems during March 2006 to January 2007

\begin{tabular}{|c|c|c|c|c|c|c|c|c|c|c|c|}
\hline Treatments & $\begin{array}{l}\text { Plant height } \\
\text { at } 120 \text { DAP } \\
(\mathrm{cm})\end{array}$ & $\begin{array}{c}\text { Plant height } \\
\text { at } 180 \text { DAP } \\
(\mathrm{cm})\end{array}$ & $\begin{array}{l}\text { No. of } \\
\text { leaves } \\
\text { plant }^{-1}\end{array}$ & $\begin{array}{l}\text { No of } \\
\text { tiller } \\
\text { hill }^{-1}\end{array}$ & $\begin{array}{l}\text { Mother } \\
\text { rhizome } \\
\text { wt. hill' } \\
\text { (g) }\end{array}$ & $\begin{array}{l}\text { Primary } \\
\text { fingers } \\
\text { No. } \\
\text { plant }^{-1}\end{array}$ & $\begin{array}{c}\text { Primary } \\
\text { fingers } \\
\text { wt. } \\
\text { plant }^{-1} \\
\end{array}$ & $\begin{array}{c}\text { Secondary } \\
\text { fingers No. } \\
\text { plant }^{-1}\end{array}$ & $\begin{array}{l}\text { Secondary } \\
\text { fingers wt. } \\
\text { plant }^{-1}(\mathrm{~g})\end{array}$ & $\begin{array}{c}\text { Total } \\
\text { rhizome } \\
\text { fresh wt. } \text { plant }^{-1}(\mathrm{~g})\end{array}$ & $\begin{array}{l}\text { Yield } \\
\text { (t/ha) }\end{array}$ \\
\hline $\mathrm{C}+\mathrm{G}+\mathrm{Misridana}\left(\mathrm{T}_{1}\right)$ & 40.01 & 48.68 & 15.42 & 10.26 & 40.52 & 53.30 & 166.66 & 16.44 & 16.08 & 224.08 & 10.49 \\
\hline $\mathrm{C}+\mathrm{L}+$ Misridana $\left(\mathrm{T}_{2}\right)$ & 35.65 & 47.18 & 14.40 & 9.10 & 32.09 & 44.66 & 181.28 & 13.48 & 15.53 & 177.35 & 7.99 \\
\hline Open $\left(\mathrm{T}_{7}\right)$ & 32.38 & 39.86 & 14.10 & 8.08 & 33.14 & 46.68 & 113.90 & 10.08 & 11.12 & 159.84 & 7.37 \\
\hline $\operatorname{Lsd}_{0.01}$ & 7.34 & 7.18 & - & 1.07 & 7.74 & 8.49 & 35.29 & 2.61 & 1.82 & 31.76 & 1.58 \\
\hline CV (\%) & 9.60 & 7.48 & 6.13 & 5.51 & 10.34 & 8.30 & 10.80 & 9.24 & 6.03 & 8.00 & 8.64 \\
\hline
\end{tabular}

LSD = Least Significant Difference; $\mathrm{C}=$ coconut $\mathrm{G}=$ guava; $\mathrm{L}=$ lemon 
Number of leaves per plant of misridana was significantly influenced by the different production systems. The maximum number of leaves (14.76 in 2005 and 15.42 in 2006)) was found in coconut+guava based $\operatorname{MAF}\left(\mathrm{T}_{1}\right)$, followed by coconut+lemon based MAF $\left(\mathrm{T}_{2}\right)$. On the other hand, the lowest numbers of leaves (12.16 in 2005 and 14.10 in 2006) were found in sole cropping of misridana (T3), which was statistically identical to that produced in the treatment $T_{2}$. The number of tillers per hill was augmented progressively (Table 5 and Table 6) as the light levels were decreased. The superior limit of the number of tillers per hill (9.42 in 2005 and 10.26 in 2006) was recorded in the treatment $T_{1}$, which followed by the treatment $T_{2}$ in both the years. On the contrary, the poorest number of tillers per hill (6.70 in 2005 and 8.08 in 2006) was experienced in the sole cropping of misridana $\left(\mathrm{T}_{3}\right)$.

Weight of mother rhizome per hill of misridana varied a lot among the different production systems. The maximum mother rhizome weight (37.80 $\mathrm{g}$ in 2005 and $40.52 \mathrm{~g}$ in 2006) was observed in coconut+guava based $\operatorname{MAF}\left(\mathrm{T}_{1}\right)$ followed by sole cropping of misridana $\left(\mathrm{T}_{3}\right)$ during both growing years. The minimum mother rhizome weight $(29.52 \mathrm{~g}$ in 2005 and $32.09 \mathrm{~g}$ in 2006) was produced under coconut+lemon based $\operatorname{MAF}\left(\mathrm{T}_{2}\right)$, which was statistically similar to sole cropping $\left(\mathrm{T}_{3}\right)$. The fresh rhizome weight was almost parallel to the weight of primary and secondary finger weight. The higher fresh rhizome weight per plant (207.8 $\mathrm{g}$ in 2005 and $224.1 \mathrm{~g}$ in 2006) was gained from the treatment $\mathrm{T}_{1}$ (coconut+guava based MAF) and was followed by $\mathrm{T}_{2}$ (coconut+lemon based $\mathrm{MAF})$ in both the years.

\subsubsection{Yield (t/ha)}

Different production systems were found to significantly influence corm yield of misridana during both years (Tables 5 and 6). The corm yield was increased at multistoried agroforestry systems as compared to that in sole cropping. Again, coconut+guava based MAF resulted better yield as compared to coconut+lemon based MAF. However, the highest yield (9.57 $\mathrm{t} / \mathrm{ha}$ in 2005 and $10.49 \mathrm{t} / \mathrm{ha}$ in 2006) was recorded under coconut+guava based MAF $\left(\mathrm{T}_{1}\right)$ during both the year. The lowest yield (6.91 t/ha in 2005 and $7.37 \mathrm{t} / \mathrm{ha}$ in 2006) was recorded in sole cropping of misridana $\left(\mathrm{T}_{3}\right)$ in both seasons, which was statistically similar to that in coconut+lemon based MAF $\left(\mathrm{T}_{2}\right)$.

\subsubsection{Economic analysis}

The production cost of misridana, initial plantation and management cost of middle and upper layer trees and the benefit cost ratio (BCR) are shown in Table 7 . The total cost of production was the highest (76117 Tk./ha) in the treatment $\mathrm{T}_{3}$ i.e. sole cropping of misridana followed by coconut+guava based MAF (46525 $\mathrm{Tk} . / \mathrm{ha})\left(\mathrm{T}_{1}\right)$.

Table 7. Economics of misridana production under coconut based multistoried cropping system (average of two years)

\begin{tabular}{|c|c|c|c|c|c|c|c|c|}
\hline \multirow{2}{*}{ Treatments } & \multicolumn{4}{|c|}{ Return (Tk/ha) } & \multirow{2}{*}{$\begin{array}{l}\text { Gross Return } \\
\left(\text { Tk. ha }{ }^{-1}\right)\end{array}$} & \multirow{2}{*}{$\begin{array}{l}\text { Total cost of } \\
\text { Production } \\
\left(\text { Tk. ha }^{-1}\right)\end{array}$} & \multirow{2}{*}{$\begin{array}{l}\text { Net Return } \\
\left(\text { Tk. ha }{ }^{-1}\right)\end{array}$} & \multirow{2}{*}{$\mathrm{BCR}$} \\
\hline & Misridana & Guava & Lemon & Coconut & & & & \\
\hline $\mathrm{C}+\mathrm{G}+$ Misridana $\left(\mathrm{T}_{1}\right)$ & 100300 & 87188 & --- & 47956 & 235444 & 46525 & 188919 & 5.06 \\
\hline $\mathrm{S}_{1}+\mathrm{L}+$ Misridana $\left(\mathrm{T}_{2}\right)$ & 77400 & --- & 51416 & 47956 & 176772 & 46132 & 130640 & 3.83 \\
\hline Open $\left(T_{3}\right)$ & 285600 & --- & --- & --- & 177330 & 76117 & 101213 & 2.33 \\
\hline
\end{tabular}

Note: $\mathrm{C}=$ coconut; $\mathrm{G}$ = guava; $\mathrm{L}=$ lemon; Misridana 40 Tk./kg, Guava 6 Tk./kg; Lemon 1 Tk./piece, Coconut 8 Tk./nut 
The lowest cost of production (46132 Tk./ha) was recorded from coconut+lemon based MAF $\left(\mathrm{T}_{2}\right)$. Higher cost of production was found in sole cropping of misridana due to higher area being cultivated $(100 \%)$ for misridana production as compared to coconut based MAF (25\%), and consequently more input cost was involved. However, the highest value of gross return (235444 Tk. /ha) was obtained from the $\mathrm{T}_{1}$ treatment (coconut+guava based MAF), which was followed by the treatment $\mathrm{T}_{3}$ (sole cropping of misridana). On the other hand, the lowest value of gross return (176772 Tk. /ha) was obtained from coconut+lemon based MAF $\left(\mathrm{T}_{2}\right)$. Among the treatments, it was found that the highest benefit-cost ratio of 5.06 was recorded from $\mathrm{T}_{1}$ treatment (coconut+guava based MAF), followed by coconut+lemon based $\operatorname{MAF}\left(\mathrm{T}_{2}\right)$. The lowest benefit-cost ratio of 2.33 was observed in $\mathrm{T}_{3}$ treatment (sole cropping of misridana). Integrations of misridana under multistoried agroforestry systems were thus clearly preferred production systems.

\section{Conclusions}

The present investigation indicates that diversification of farming system and growing medicinal plants as ground layers crops in coconut orchard is a viable option for increasing income of farmers. The three medicinal plants namely, aloe vera, asparagus and misridana have been grown successfully as intercrops in the floor of coconut orchard. The presence of tree canopies did not influence growth and yield of economically important organs of the medicinal plant species, although some adverse effect of trees was obvious in plants growing nearer to the tree rows. From an economic point of view, it was also pragmatic that misridana and asparagus medicinal crops were found to be better yielding and more remunerative in comparison with aloe vera under multistoried agroforestry systems. Nevertheless, the overall performance of multistoried agroforestry systems implies that, misridana, asparagus and aloe vera would be grown under multistoried agroforestry systems considering the additional return per investment in terms of money and time. Medicinal plants based agroforestry systems may therefore, be adopted as suitable alternative farming systems for diversification and boosting the economy of farmers in Bangladesh.

\section{Referecnes}

Chadhar, S. K. and Sharma, M. C. 1996. Survival and yield of four medicinal plant species grown under tree plantations of Bhataland. Vaniki Sandesh, 20(4): 3-5.

FAO. 2004. In situ conservation of wild plants genetic resources: A status review and action plan. Document by FAO and IUCN, Rome. 83 p.

Maheswari S. K., Dhantonde B. N., Yadav S. and Gangrade S. K. 1985. Intercropping of Rauvolfia serpentina for higher monetary returns. Indian Journal of. Agricultural Science, 58:108-111.

Mishra, R. K. and Pandey, V. K. 1998. Intercropping of turmeric under different tree species and their pattern in agroforestry systems. Range Management Agroforester, 19: 199-202.

Pareek, S. K. and Gupta, R. 1984. Exploratory studies on yield and comparative economics of medicinal plants based cropping systems in north-western India. Annals of Agricultural Research, 5: 169177.

Prajapati, N. D., Purohit S. S., Sharma A. K. and Kumar, T. 2003. A Handbook of Medicinal Plants. Agribios (India), 553 p.

Rao, M. R; Palada, M. C. and Becker, B. N. 2004. Medicinal and aromatic plants in agroforestry systems. Agroforestry Systems, 61:107-122.

Sujatha, S., Bhat, R., Kannan, C. and Balasimha, D. 2011. Impact of intercropping of medicinal and aromatic plants with organic farming approach on resource use efficiency in arecanut (Areca catechu L.) plantation in India. Industrial Crops and Products, (33) 1:78-83.

Vyas, S. and Nein, S. 1999. Effect of shade on the growth of Cassia ungustifolia. Indian Forester, 125: 407-410. 